\title{
Bizans Prensesi Anikia luliana'nın Baniliği ve Aziz Polyeuktos Kilisesi ${ }^{1}$
}

\author{
Dilek MAKTAL CANKO²
}

Öz

Bizans İmparatorluğu'nda imparatoriçeler ve soylu kadınlar; malın, mülkün ve soyluluğun hamili olarak manastırlar kurdular, hastaneler inşa ettirdiler, el yazmaları ürettiler ve sanat hamisi olarak yetiştiler. Kaynakların yetersizliği nedeniyle 11. yüzyıl öncesine ilişkin bilgilerimizin kısıtlı olmasına rağmen; 6 . yüzyılda yaşamış olan prenses Anikia luliana'nın sanat hamisi olarak yetişen soylu bir kadın olduğu bilinmektedir.

Anikia luliana, imparatoriçe adayı olarak yetiştirilmesinin ardından hayallerinin gerçekleşmemesi nedeniyle hayal kırıklığı yaşamış ve dönemin imparatoru lustinianus ile sanatsal alanda güç savaşına girmiştir. Bu güç savaşının ürünü Iuliana'nın baniliğinde yaptırılmış Aziz Polyeuktos Kilisesi olmuştur. Pahalı işçiliği, şatafatlı sanat eserleri ile kilise, Iuliana'nın konumunun ve gücünün büyüklüğünü kanıtlamakla birlikte, zamana meydan okuyan banisini de ölümsüzleştirmiştir.

$\mathrm{Bu}$ makalede, Bizans prensesi Anikia luliana'nın, mimari ve süsleme özellikleri bakımından çağının ötesinde bir yapı olan Aziz Polyeuktos Kilisesi'ne maddi destek vermesinin nedenleri incelenmiş ve bir imparatorluk kadınının mimari unsurlar ile sosyal hayatta ve politikada yer alma süreci tartışılmıştır.

Anahtar Kelimeler: Anikia Iuliana, Aziz Polyeuktos Kilisesi, Bizans’ta Sanat Hamiliği, Bizans Kadınları

\section{Art Patron of Byzantine Princess Anicia Juliana and Hagios Polyeuktos Church}

\begin{abstract}
In the Byzantine Empire, empresses and noble women as a owner of the goods, property and nobility established monasteries, built hospitals, produce manuscripts; and they were trained as a patron of the arts. Despite limited our knowledge of the pre- $11^{\text {th }}$ century due to the lack of resources, it is known the princess Anicia Juliana lived in Constantinople in the $6^{\text {th }}$ century was a noble woman who was trained as a patron of arts.

She was disappointed for not being empress. Then she competed about artistic field with emperor Justinianus in the period. This product of the competition was Hagios Polyeuktos Church. The church with expensive workmanship and ornate artwork has proved the power of Anicia Juliana.

In this article, it is examined the reasons why the Byzantine prince Anicia Juliana gave financial support to the Hagios Polyeuktos Church which is a structure beyond the age of architectural and decorative features and discussed the process of being involved in social life and politics with the architectural elements of an imperial woman.
\end{abstract}

Key Words: Anicia Juliana, Hagios Polyeuktos Church, Patron of Arts in Byzantium, Byzantine Women

\footnotetext{
${ }^{1}$ Bu çalışma, 12-14 Mayıs 2016 tarihlerinde Adnan Menderes Üniversitesi tarafından düzenlenen "Kültürel Miras ve Kadın" başlıklı sempozyumda bildiri olarak sunulmuştur. Makale olarak hazırlanırken bazı eklemeler ve düzenlemeler yapılmıştır.

${ }^{2}$ Araş. Gör. Dr. Ege Üniversitesi Edebiyat Fakültesi Sanat Tarihi Bölümü,

*Ilgili yazar / Corresponding author: dilek.m.canko@ege.edu.tr

Gönderim Tarihi: 19.04.2017

Kabul Tarihi: 17.05.2017
} 


\section{GiRiş}

Antik Yunan'da ve Roma'da olduğu gibi halka; imparatorun, imparatoriçenin ve saray görevlisinin önemini, cömertliğini ve toplumsal bilincini ifade eden hizmetler sunma sorumluluğu Bizans sisteminin de bir parçasıydı. Bu sistem gereği imparatorluk ailesi üyeleri genellikle büyük maddi desteğe ihtiyaç duyan görkemli inşa faaliyetlerinin baniliğini yapmışlardır. Bu faaliyetler yoluyla banilerin, Tanrı'ya şükretme ve ona hediye sunarak manevi rahatlama, ruhlarının kurtuluşu için yakarma ve toplumsal statünün artışının sağlanması fırsatlarını elde etmesi; kadınların da baniliğe ilgi göstermesine neden olmuştur. ${ }^{3}$

Bununla birlikte, anıtsal yapıların baniliği ile imparatorluk kadınlarının elde ettiği önemli bir fırsat daha olmuştur. İmparatorluk kadınları, sözcüklerle yapamadığı kamu söylemini kurdukları anıtlar ile sağlamaya çalışmışlardır. Roma dönemi ve Erken Hıristiyanlık döneminde heykeller ve anıtlar ile sağlanan kamu iletişim biçimi, Bizans döneminde anıtsal yapıların baniliği ile devam ettirilmiştir (Brubaker, 1997, s. 52; James, 2014, s. 65). Bu anlamda Augusta Helena (250-330), İmparatorluk ailesi üyesi ilk Hıristiyan bani olarak Bizans için önemli bir sembol olmuştur. ${ }^{4}$ Helena'nın ardından gelen erken Hıristiyanlık ve erken Bizans dönemi imparatorluk kadınları banilikleri ile kendilerine, Helena ile paralel bir yol çizmişlerdir (Brubaker, 1997, s. 59-60). Theodosios Hanedanlığı'na mensup kadınlar da Helena'yı takip ederek politik varlıklarını banilik yoluyla sağlamlaştırmaya çalışmışlardır. ${ }^{5}$ Özellikle, Aelia Eudoksia ve Aelia Athenais Eudokia, Helena gibi Kutsal topraklara gitmiş ve banilik faaliyetlerini orada sürdürmüşlerdir (Brubaker, 1997, s. 90; Kleinbauer, 2006, s. 125). Athenais Eudokia'nın kızı Liciana Eudoksia ve onun kızı Placidia ve torunu Anikia luliana da hanedanlığın geleneğine uyarak banilik yoluyla kamu iletişimini sağlamaya çalışan imparatorluk ailesi üyesi kadınlar olmuşlardır.

Bu kadınlar banilik faaliyetleri ile yaşadıkları hayat için Tanrı'ya şükranlarını sunmak, dinsel görevlerini yerine getirmek gibi manevi amaçları mı hedefliyorlardı? Ya da kamu iletişimini sağlamak, politik varlıklarını sürdürmek veya varlıklarını göstermek gibi daha dünyevi amaçlara mı sahiplerdi? Bu makalede, Anikia Iuliana ve baniliğini yaptığı Aziz Polyeuktos Kilisesi incelenerek bu soruya luliana özelinde yanıt verilmeye çalışılacaktır.

\section{ANIKIA IULIANA'NIN YAŞAMI}

Batı Roma Imparatoru Flavius Anicius Olybrius (472-473) ve karısı İmparator III. Valentinianus'un ve Liciana Eudoksia'nın kızı 'Genç' Placidia'nın çocuğu olarak 461 (ya da 463) yılında Konstantinopolis'te dünyaya gelen Anikia luliana (Kaegi, 1991, s. 99100), muhtemelen çok iyi bir eğitim almıştı. İmparator soyundan geldiği için sarayda patricia unvanına sahipti ve dolayısıyla sarayda yapılan tüm törenlerin bir üyesi idi. Annesi Placidia, büyük annesi Liciana Eudoksia ve büyük büyük annesi Athenais Eudokia'nın imparatoriçe olmaları ve saraydaki şaşaalı yaşamları, muhtemelen kendisinin de imparatoriçe olma hayalleri kurmasına neden olmuştu. Bu amaçla 478'de

\footnotetext{
${ }^{3}$ Bizans'ta Kadın Baniler hakkında daha fazla bilgi için bknz: Canko 2016. 351-400.

${ }^{4}$ Augusta Helena'nın Hıristiyan Bizans dünyasına, sanatına katkısı için bknz: Angelova 2015, 134-146; ardından gelen imparatorluk kadınlarına etkisi hakkında daha geniş bilgi için bknz: Brubaker 1997, 52-75.

${ }^{5}$ Theodosios kadınlarının baniliği ile ilgili daha geniş bilgi için bknz: Erbilgin 2010.
} 
general Areobindus ile evlenmiş ve 512'deki generali imparator yapmaya yönelik girişim başarısızlıkla sonuçlanınca büyük hayal kırıklığına uğramıştı (Connor, 2011, s. 158).

Soylu, zengin ve büyük Romalı ailelerin ikisine mensup olan Anikia, ailesinin olanaklarını kullanarak döneminin dini ve siyasi olaylarında önemli bir rol oynayacak kadar etkili bir kişilik olmuştu. 484-519 yılları arasında Ortodoks-monofizit akımların çekişmesinden doğan Akakios'un başlattığı dinsel akımda Roma ve Konstantinopolis kiliseleri arasındaki anlaşmazlıkta aktif rol alması ve kiliseler arasındaki sürtüşmeye son vermek amacıyla Papa Hormisdas ile mektuplaşması döneminin politikasına etkisini ve gücünü kanıtlamaktadır (Necipoğlu, 1993, s. 274).

Anikia Iuliana, antik doktor Dioskorides'in De Materia Medica (Tıbbi Maddelere Dair) ${ }^{6}$ isimli bitkilerin, otların ve köklerin tıbbi amaçlarla nasıl kullanılacaklarına dair talimatlar veren eserinin gösterişli bir şekilde süslenmiş 512 tarihli Viyana kopyasında (cod. med. gr. 1, fov. 6v) tasvir edilmiştir (Şekil 1). Antik çağın sonlarında ve Bizans döneminde temel bir tıp ve eczacılık kaynağı olan bu çalışmada, günümüzde de örneklerinin görülebileceği 383 Akdeniz bitkisi resmedilmiştir. 'Anikia Iuliana Kodeks'i ismiyle bilinen bu yazmanın 6. yaprağının arkası günümüze gelen en eski hitap sayfasıdır ve banisinin tasvirini barındırmaktadır (Janick ve Stolarczyk, 2012, s. 10). ${ }^{7}$

Törensel ifadeler taşıyan bu resimde Iuliana, katlanır ayaklı bir tabure üzerinde oturmuş cepheden ve sağ eliyle altın sikkeler dağıtırken tasvir edilmiştir. Altın sikkeler Iuliana'nın sağında bulunan Yüce Gönüllülük ( $\mu \varepsilon ү \alpha \lambda$ kişileştirmesi tarafından tutulan bir çantadan gelmektedir. Iuliana'nın solunda ise, kucağında bir kitap tutan Bilgelik ( $\varphi$ póvnбıs-phronēsis) kişileştirmesi tasvir edilmiştir (Angelova, 2015, s. 226). Bu kişileştirmeler, Iuliana'nın bilgece davranışını ve cömertliğini alegorik yoldan anlatır. Prensesin yanında açık kitabı tutan bebek figürü ise kendini imar faaliyetlerine adamış prensesin sanat hamiliğine vurgu yapar (Connor, 2011, s. 164).

Taban mozaikleri ve Kıpti sanatının tekstil örneklerinde görülen bir yuvarlağın içinde sekiz kollu yıldız tasarımı el yazmaları arasında benzersiz ve eşsizdir. Tasviri çevreleyen kırmızı üçgenlerin içinde altın yaldızla IOULIANA ismi hecelenmektedir (Kiilerich, 2010, s.171). Ortadaki sekizgenin lacivert fonunun boyanmasında yalnızca Afganistan'da çıktığı söylenen yarı değerli lacivert taş (lapis lazuli) tozu kullanılmıştır. Genel olarak renklerin parıltısı, prensesin pozu ve yerleştirildiği ortamla para bağışlayışı çok açık bir biçimde tek bir fikrin birbirini tanımlayan yönlerini oluştururken, prensesin cömertliğini ortaya koymaktadır (Cutler, 2010, s. 137). Nitekim orta bölümdeki canlı maviyi çevreleyen ve sekizgen oluşturan ip ile çember oluşturan ip arasında kalan mavi boşluklarda minik figürlerin inşa faaliyeti ile tasvir edilmesi minyatürü kilisenin yapımı ile ilişkilendirmiştir. Sahnelerin birinde bebek işçiler tahta kirişleri çekiçle yerine oturturken, diğerinde iskelelerde durup ipleri çeken figürler görülmektedir. Bu sahnelerin her biri yapının inşası ile ilgili sahneler olduğu açıktır (Connor, 2011, s. 164).

Üst giysisi baştan aşağıya altın çizgili, ayak taburesi de aynı tarz altın süslemeli olan Anikia luliana, bu tasviri ile tahta oturan ve iki yanında meleklerle tasvir edilen Tanrı

\footnotetext{
${ }^{6}$ El yazmasının 1689 yılında Peter Lambeck tarafından tanıtılmasıyla başlayan bilim dünyasına kazandırıma çalışmaları için bknz: Ciotta, 2012, s. 101.

${ }^{7}$ El yazması minyatürleri hakkında daha geniş bilgi için bknz: Brubaker, 2002, s. 289-214.
} 
Anası'na benzemektedir. Anikia, Floransa fildişi panelindeki İmparatoriçe Ariadne ${ }^{8}$ gibi sağ elini saygı işareti yapmak için yana doğru açmış ona bir kitap sunan küçük figürü işaret etmektedir. Anikia luliana'nın burada erguvan ve altın renklerle, imparatorluk diademi giyerek ve imparator gibi tahta oturarak tasvir edilmesi ve genellikle imparator tasvirlerinde bulunan yana doğru açılan el; onun imparatoriçe olduğunu düşündürtmektedir (James, 2001, s. 144; Kiikerich, 2010, s. 186; Angelova, 2015, s. 227). ${ }^{9}$ Ancak luliana bir agusta değildi. Entelektüel, soylu ancak imparatoriçe gibi tasvir edilmesi onun masum olmadığını da göstermektedir. Çağdaşları da muhtemelen ayrıntıları bu şekilde okumuştu (Angelova, 2015. s. 229).

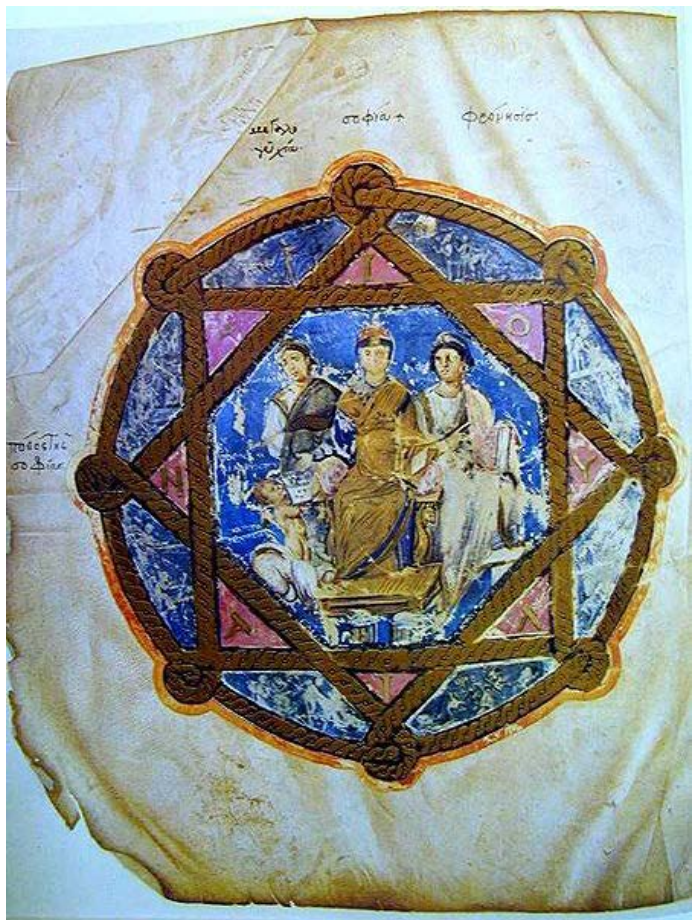

Şekil 1: Anikia Iuliana'nın Portresi, Viyana Dioskorides Yazması, cod. med. gr. 1, fov. 6v, 6. yüzyıl başı, Österreichisches Nationalbibliothek Viyana, Avusturya (Baker, 2013, s. 115,

Fig: 7)

Ayrıca luliana, ithaf yazıtında da imparatorluk dilini kullanmıştır. Birbirinin içinden geçen ve bükümlü bir iple çizilmiş sekizgen çerçevenin iç kısmında ince siyah bir şerit üzerinde Grek harfleriyle yazılmış bir yazıt okunmaktadır. Bu her bir dizesinin Iuliana'nın adının bir harfiyle başlayan akrostişli bir dizedir ve ilk dize Anikia'nın başının üzerinden başlar (Connor, 2011, s. 164-165):

"Işte tüm iyi övgülerle, Kraliçem, Honoratoe sana ilahiler söyler ve seni över. Üyesi olduğun ailenin, Anicilerin yüce gönüllülüğü, tüm dünyaya yayılarak sana övgüler söyletir. Çünkü sen, o göklere yükselen güzelliği, Tanrı'nın kilisesini inşa ettin."

Bu dizelerde yazılması nedeniyle bilgi sahibi olduğumuz kadarıyla bu kitap, luliana'ya

\footnotetext{
${ }^{8}$ 5./erken 6. yüzyıla tarihlenen üzerinde imparatoriçe Ariadne'nin tasviri olduğu düşünülen fildişi panel. Bu panel üzerinde gördüğümüz imparatorlara ait özellikler İmparatoriçe'nin erken Bizans döneminde önemine ve gücüne işaret etmektedir. Daha ayrıntılı bilgi için bknz: Canko, 2016, s. 239-241.

9 Anikia luliana'nın tasvirindeki sembollerin anlamları hakkında daha geniş bilgi için bknz: Kiilerich, 2010, s. 173-178.
} 
512 yılında boğazın Asya yakasındaki Konstantinopolis kasabalarından biri olan Honoratoe'deki Tanrı Anası Kilisesi'nin inşasına bani olduğu için kasaba halkı tarafından bir teşekkür olarak sunulmuştu (Kiilerich, 2010, s. 171; Cormack, 2000, s. 41; Angelova, 2015, s. 226). ${ }^{10}$ Görünüşe göre, bu hediyeyi verenler, bir imparator kızına ve bir kilise banisine tıbbi bilgiler içeren bir kodeksi vermeyi uygun görmüşler (Angelova, 2015, s. 177). Anikia'nın tasvirindeki süs ve ihtişam Anikia'nın kişiliği hakkında bize bilgi sunarken tasvirdeki alegorik anlamlar ve dizelerde geçen "Kraliçem" kelimesi de halkın luliana'yı bir imparatoriçe gibi gördüğünü ve benimsediğini kanıtlamaktadır.

\section{ANIKIA IULIANA'NIN BANILIK FAALIYETLERI VE AZIZ POLYEUKTOS KILISESi}

Anikia, iyi bir dindar olarak annesi Placidia ve büyük annesi Licinia Eudoksia ve büyük büyük annesi Athenis Aelia Eudokia'nın banilik geleneğini devam ettirmiş ve erken Hıristiyan ve erken Bizans dönemi için çok önemli bir kadın bani olmuştur. Konstantinopolis'in muhtemelen varoşlarından biri olan Honoratoe semtinde olduğu bilinen Tanrı Anası Kilisesi'nin öyküsü ne yazık ki günümüze ulaşamamıştır (Nathan, 2006, s. 435) ancak, Iuliana'nın banisi olduğu diğer kilise olan Aziz Euphemia Kilisesi'nin birkaç kuşak süren inşa hikayesi bilinmektedir.

Lucinia Eudoksia (422-462), 440-450 arasında Azize Euphemia'ya ithaf edilen kiliseyi kurmuş, kızı Placidia 461-472 arasında kilisenin süsleme programı yapmış ve Anikia Iuliana ise 527-528 yılında ölümünden önce kiliseyi tamamlamıştır (Grant, 2000, s. 77). Anikia'nın sıkı sıkıya ilkelerini benimsediği Khalkedon Konsili'nin bağlı olduğu Azize'ye ithaf edilen bu kiliseyi tamamlaması dini, siyasi ve sanatsal açıdan atalarının izinden gittiğini ifşa etmektedir.

Honoratoe'deki Tanrı Anası (Theotokos) Kilisesi ve Azize Euphemia Kilisesi günümüze kadar ulaşamamışlardır ve ne yazık ki yerleri bile bilinmemektedir. Ancak erken Hıristiyanlık ve erken Bizans dönemi için önemli bir bani olduğu anlaşılan Anikia luliana'nın Konstantinopolis'te döneminin en görkemli kilisesinin banisi olduğu 1960 yılında tesadüfen yapılan çalışmalar sırasında keşfedilmiştir.

1960 yılında İstanbul'un Saraçhane semtinde, yeni bir belediye binası inşası için çalışmalara başlandığında, buldozerlerin büyük mermer bloklar, tuğla ve taş parçaları ile karşılaşmaları nedeniyle yapım faaliyetleri durdurulmuş ve arkeologlar yapının kimliğini belirlemek üzere çalışmalara başlamışlardır. 1964-1969 yılları arasında İstanbul Arkeoloji Müzesi Eski Çağlar Bölümü ve Dumbarton Oaks işbirliği ile gerçekleştirilen ve altı dönem boyunca süren kazılar sonucunda çok görkemli bir kilise ile karşı karşıya olunduğu fark edilmiştir (Şekil 2). Dumbarton Oaks'tan Martin Harrison ve İstanbul Arkeoloji Müzesi'nden Nezih Fıratı'nın (1965, s. 230-236; 1966, s. 222-238; 1967 , s. 273-278; 1968, s. 195-216) yapının mimarisi ve süslemeleri, Cyril Mango ve İhor Ševčenko'nun $(1961,243-247)$, ise yıkıntılar arasından gün ışığına çıkan Grekçe bir yazıt üzerindeki çalışmaları, kilisenin isminin ve banisinin belirlenmesini sağlamıştır. Kilise, Romalı-Bizans Prensesi Anikia Iuliana'nın baniliğini yaptığı Aziz Ployeuktos

10 8. yüzyıl bilgini Theofanes'in de Kroniğinde Anikia hakkında, "Honoratoe'deki Tanrı Anası Kutsal Kilisesi'ni kuran en soylu luliana" diye bahsetmesi (Theophanes Confessor, 1997, s. 239), bu kilisenin Anikia tarafından baniliği yapılan Tanrı Anası Kilisesi olduğunu göstermektedir. Bununla birlikte kitap ne kadar teşekkür olarak sunulsa da luliana, bu kadar ince işçilikli ve pahalı bir eserin oluşumunda maddi destek vermiş olmalıdır. Anikia, bu tasvir ile kilisenin ve bu değerli kitabın banisi olarak tarihe kaydını geçiriyordu. 
Kilisesi'dir.
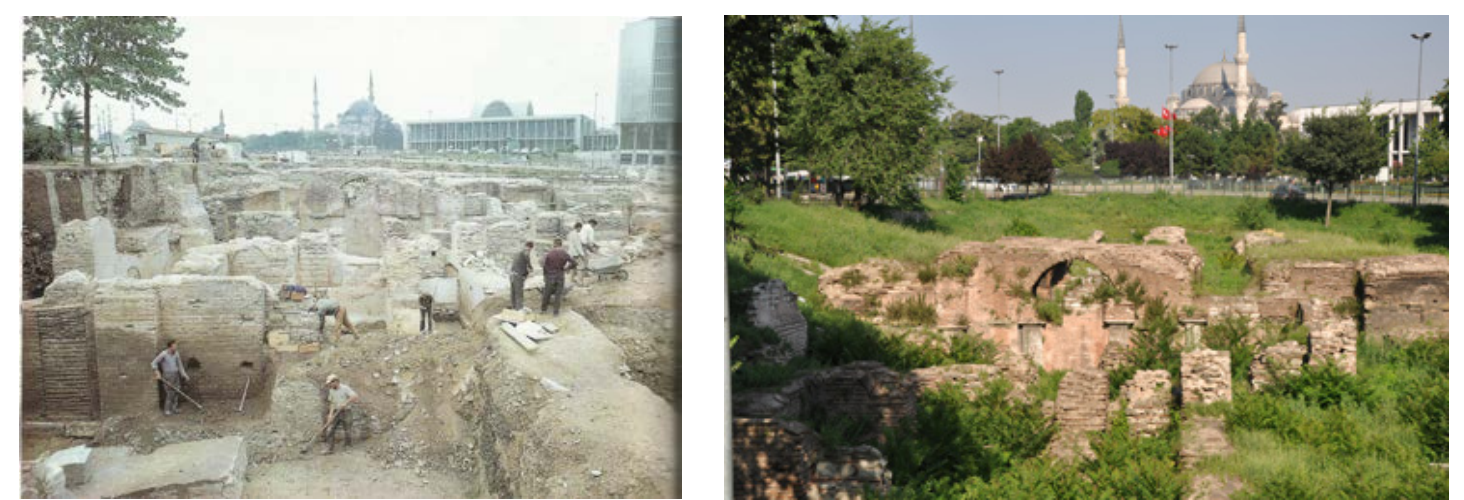

Şekil 2: Aziz Polyeuktos Kilisesi kazı alanından genel görünüm (Harrison, 1989, Fig 29) ve alanın günümüzdeki durumu (http://www.hayal-et.org/i.php/site/building/polyeuktos kilisesi, E.T: 17.05.2017)

Aziz Polyeuktos Kilisesi, Mese caddesi boyunca Theodosios Forumu'ndan geçerek Havariyyun Kilisesi'ne varan resmi geçit güzergahının üzerinde ve Anikia'nın kendi sarayının yanında çok önemli bir konumda bulunmaktaydı (Şekil 3) (Freely ve Çakmak, 2005 , s. 66). 524-527 yılları arasında ${ }^{11}$ inşası sürdürülen kilise, muhtemelen o zamana kadar Konstantinopolis'te görülen en muhteşem yapı idi. ${ }^{12}$

111964 yılında bulunan yapının inşasında kullanılan tuğlaların büyük çoğunluğunun üzerinde tarih bildiren haç şeklinde damgalar görülmüştür. Bunlar edebi kaynaklardaki kronolojik bilgiler ile çakıştııılığında kilisenin inşasına 524 yılında başlandığı ve Anikia'nın ölümünden bir yıl önce 527 yılında tamamlandığı anlaşılmaktadır (Ciotta 2012, 105). Bununla birlikte, Tourslu Gregorius'un hikayesi de yapının lustinianos'un hükümdarlığının başladığı yıl olan 527 yılında tamamlandığını söylemektedir. Kazılar esnasında bulunan sikkeler, kilisenin II. Isakios Angelos'un hükümdarlığının bitiminden kısa bir süre sonra yıkıldığını göstermektedir. 1010 yılındaki deprem bu tahribata neden olmuş olabilir (Müller-Wiener 2007, 191). Bu tahribat muhtemelen şehrin Latinler tarafından ele geçirilmesi esnasında daha da artmış olmalıdır. Çünkü Batı Avrupa'da özellikle Venedik'te kiliseye ait mimari parçalar bulunmaktadır (Freely ve Çakmak, 2005, s. 66; Mango, 2006, s. 84). Yapının Venedik'e götürülen pek çok parçası San Marco Kilisesi'nin inşasında kullanılmıştır. Götürülemeyen parçalar ise, Konstantinopolis'teki diğer kiliselerde kullanılmış olmalıdır.

${ }^{12}$ Kilisenin kalıntıları, günümüzde İstanbul'un Saraçhane semtinde park içinde sergilenmektedir ve ziyaretçilere açıktır. 


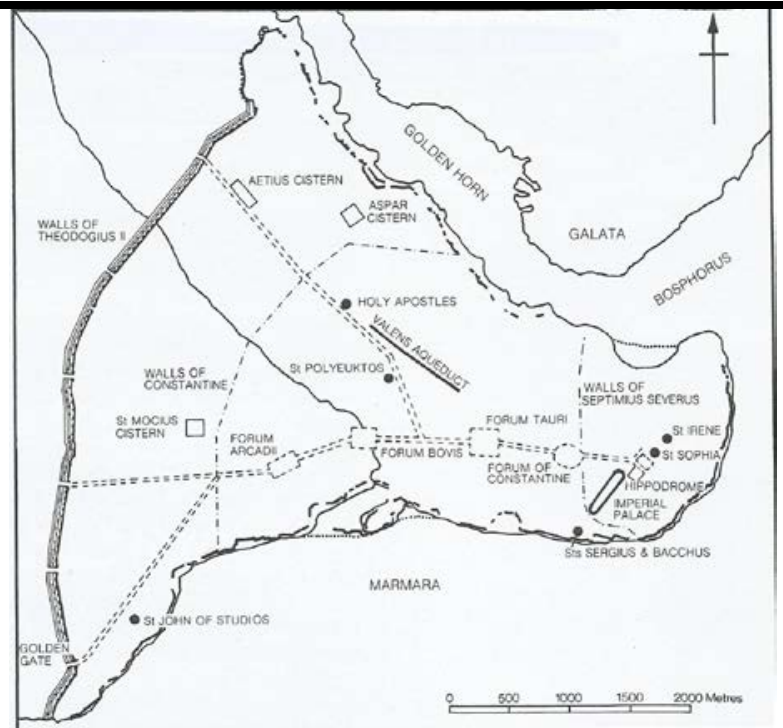

Şekil 3: Aziz Polyeuktos Kilisesi'nin yerini gösteren Bizans dönemi Konstantinopolis planı (Harrison, 1989, s. 35, Fig: 30)

1960’ı yıllar boyunca Martin Harrison başkanlığında kazıların devam etmesi kilisenin görkemini ve büyüklüğünü de gözler önüne sermiştir. Sadece temelleri günümüze ulaşabilmiş kilisenin yapı strüktürünü dikkatli bir şekilde inceleyen Amerikalı arkeolog Harrison, kilisenin planını ve restitüsyon çalışmasını yapmıştır. Kilise her kenarı 52 metreden biraz daha az uzunluğa sahip devasa boyutlarda kare bir anıttı. Narteksin batısında atrium ve onun da kuzeyinde vaftizhane olabilecek büyük ve karmaşık bir yapı bulunmaktaydı. Üstteki nişlerle bölünmüş ana mekan, iki temel duvarların arasında nefleri birbirinden ayıran sütun sıralarını bulunduruyordu (Harrison 1989, s. 127-135) (Şekil 4).
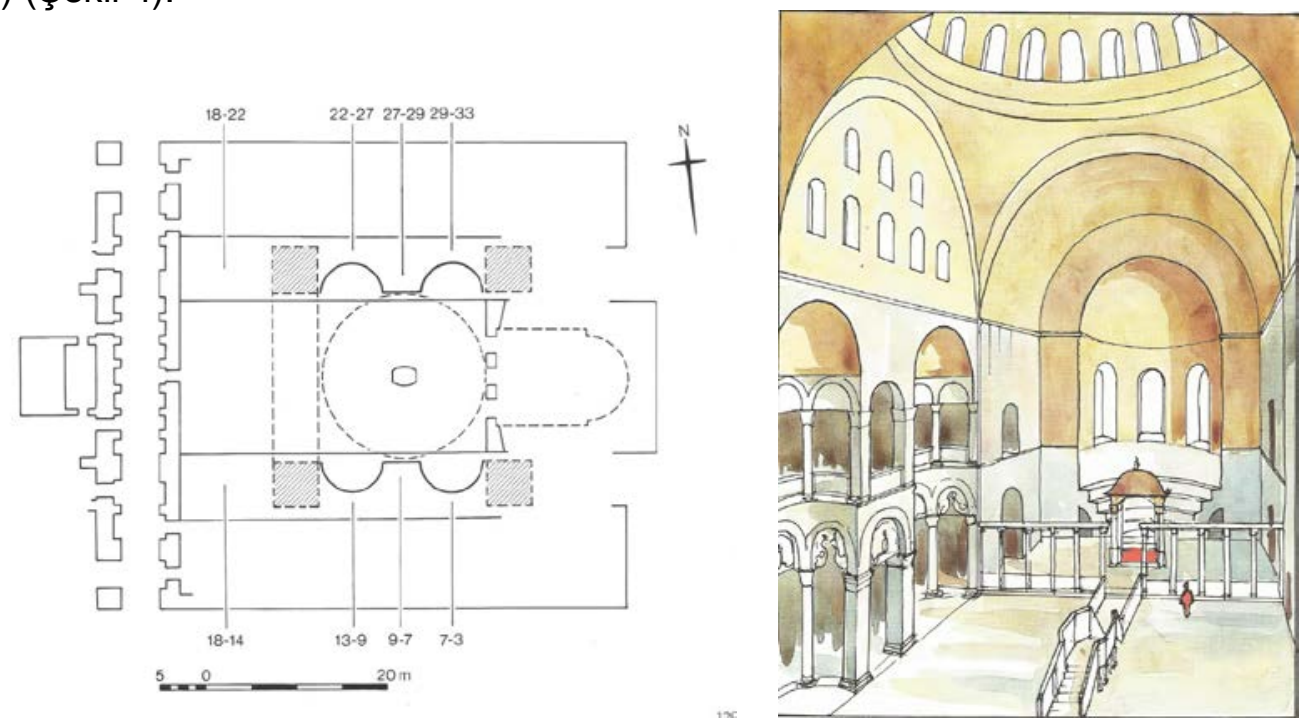

Şekil 4: Kilisenin Planı (Harrison 1989. 129 fig: 169) ve batıdan doğuya apsise doğru restütisyon çizimi (Harrison, 1989, s. 126, Fig: 167)

Kare bir yapı olan kilisenin ana girişine avludan sadece temelleri ve en alt basamağı günümüze kalan bir merdivenle ulaşılabilmekteydi. Merdivenin uzunluğu 5 metre idi. Kare plan ve naos ile nefler arasındaki temel duvarların aşırı kalınlığı kilisenin kubbe ile örtülmüş olabileceğini düşündürtmüştür (Harrison, 1989, s. 134; Mango, 2006, s. 84; Müller-Wiener, 2007, s. 190). Kubbe, orta nefin duvarlarının kalınlığı üzerinde yükselmekte, nefin geri kalan üçte ikisi ise tonozla örtülmüş bir kubbeli bazilika 
olmalıdır. Bu sistem Ayasofya'daki gibi her iki yandaki iki eksedraya dayanan pencerelerle hafifletilmiş iki kemeraltı duvarı meydana getirmekteydi. Aziz Polyeuktos Kilisesi; iki sütunla üç kemere bölünmüş, iki katlı ve yarım daire biçimli dört eksedrayla desteklenen, kubbeli bir merkezi planın görüldüğü ilk yapı olması bakımından da Bizans sanatı açısından önemli bir yapıdır (Yerasimos, 1998, s. 170) (Şekil 5).

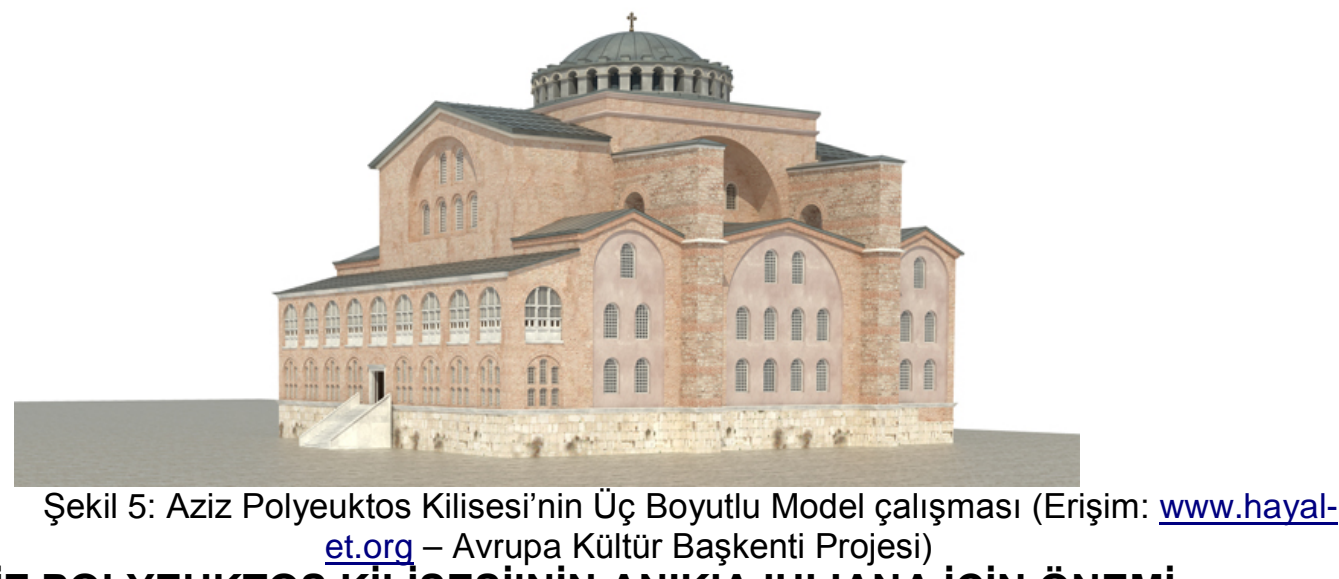

\section{AZIZ POLYEUKTOS KILISESI'NIN ANIKIA IULIANA IÇIN ÖNEMI}

Kilisenin Bizans sanatı açısından önemi sadece bilinen ilk kubbeli bazilika olması ile kalmamaktadır. Cyril Mango ve Ihor Ševčenko, bu yıkıntılar arasında ortaya çıkan Grekçe yazıtlarda, Yunan Antolojisi'nde korunmuş olan uzun bir şiirin sözcüklerini tanımayı başarmışlardır (Mango ve Ševčenko, 1961, s. 243-247). Bu yazıın Yunan Antolojisi'nde bahsi geçen şiir olduğunun anlaşılması, kilisenin Aziz Polyeuktos Kilisesi olduğunu kesinleştirmiş ve kiliseyi baştan sona dolanan şiirin tümünün bilinmesini ise banisi hakkında önemli tanımlamalar yapmayı sağlamıştır.

Kilisenin naosundaki kemerler üzerinden başlayarak narteksinde ve atriumunda da devam eden ve kiliseyi dolanan yetmiş altı dizellik şiir, kilisenin inşa süreci ve Anikia'nın hayatı hakkında önemli bilgiler sunmaktadır. Epigramın ilk kırk bir dizesi kilisenin içini dolanan bir şerit içinde nefin güneydoğu köşesinden başlayıp saat yönünde uzanarak nefin çevresindeki nişlerin kemerlerine ve kornişlere, geri kalanı ise narteks ve atriuma kazınmıştı (Harrison, 1989, s. 127).

Yetmiş altı dizelik şiirin ilk on mısrası, büyük büyük annesi II. Theodosios'un eşi Athenais Eudokia'dan bahsederek ailesinin gücünü ve şöhretini ön plana çıkarmaktadır. Bu epigrama göre buradaki ilk kilise, küçük ve daha az gösterişli olarak Athenais Aelia Eudokia tarafından yaptırılmıştır. ${ }^{13}$ Eudokia, 251 yılında şehit edilen bir Roma lejyoner askerin Polyeuktos'un kemiklerini Melitene'den (Malatya) getirtmiş ve onun adına bir kilise inşa ettirmiştir (Yerasimos, 1998, s. 170). Anikia, sarayının duvarları içinde bulunan bu kiliseyi genişletip süsleme ile zenginleştirmiştir:

"Tanrıyı onurlandırmak adına istekli olan Imparatoriçe Eudokia, tanrısal ilhamlı Polyeuktos'a bir mabet yapan ilk kişiydi. Fakat onu, bunun kadar güzel ve büyük yapmadı. Bir kısıtlama ve yeterli kaynağa sahip olamamasından değil - bir Kraliçe'nin ne eksiği olabilirdi ki?- ailesinin ve soyundan gelenlerin, onu daha da güzelleştirmek adına bilgiye ve kaynağa sahip olacakları ilahi bir biçimde içine doğdu. Bu soydan

\footnotetext{
${ }^{13}$ Athenais Aelia Eudokia'nın banilik faaliyetleri hakkında daha geniş bilgi için bknz: Klein, 2014, s. 85-95.
} 
Iuliana, kutsanmış ebeveynlerin parlak ışığı, onların asil kanının dördüncü nesilde taşıyan o Kraliçe'nin, ki o soydan en harika çocukların anasıydı, ümidini boşa çıkarmadı. Aslen küçük olan bu yapıyı şu anki ölçüsüne ve şekline getirdi."(Paton, 1916, s. 33).

Galla Placidia'nın Ravenna'da Aziz Ioannes'e adanan kilisesinde sülalesinin tasvirlerini yaptırarak imparatorluk aile bağlarını övmesi (Brubaker, 1997, s. 53), Anikia Iuliana tarafından da benimsenmiş gözükmektedir.

Epigram 28-31 numaralı dizeler, Iuliana'nın yaptırdığı diğer kiliselere de değinerek onun baniliğini ve yüce gönüllügünü över ve ardındaki dizelerde kendisinin ve ailesinin korunması ve ölümsüzlüğü için dua eder:

"Sen bile ellerinin Tanrı'ya adanmış kaç ev yaptığını bilmiyordun; sadece sen bana kalırsa, dünyanın her köşesinde sayısız tapınaklar yaptırdın ve her zaman ilahi Tanrı'nın hizmetkarlarını yücelttin." (Paton, 1916, s. 8-9)

Ardındaki dizeler ise (32-41), luliana'nın ve ailesinin Tanrı'ya hediyeleri ve adakları nedeniyle tüm Göksel varlıklar tarafından korunacağını bildirir:

"Ailesinin iyi işleri ile onların ayak izlerini takip eden O (Iuliana), her zaman dindarlık yolunda gitti ve ailesini ölümsüz yaptı. Bu nedenle, tapınaklar inşa edip hediyeler verdiğin Göksel Kralın tüm görevlileri, memnuniyetle kızları ve oğlu ile onu korudu ve Güneş yanan arabasını sürdüğü sürece en hayırlı ailenin şanının sürekliliği ölçülemeyebilir." (Paton, 1916, s. 8-9)

Antolojiye göre, kilisenin önündeki nartekste yazılı olan sonraki dizeler (42-55) Iuliana'yı yüceltirken, kilise hakkında da önemli ipuçları vermektedir:

"Konstantinos'tan sonra, Theodosios'un kutsal altın ışığından sonra ve bir çok krali atalarından sonra bir kaç yıl içinde soyuna layık böylesine değerli bir işi başaran Iuliana'nın çalışmalarının ilahiliğini anlatmak için kağıtlar yetmez. Bir tek O, Tanrı'ya bir ev hediye ederek şöhret olan Süleyman'ın bilgeliğini aşmış ve zeminden yıldızlara, doğudan batıya her iki taraftaki gün ışığı ile parlayarak kendini genişleten Tanrı evi ile zamanın sesi olmuştur." (Paton, 1916, s. 8-11)

Bu dizeler ile Iuliana, Hz. Süleyman'ın eserinden daha görkemli bir eser yaratıp onun bilgeliğini ve büyüklüğünü aştığını söyleyerek kendini Süleyman ile kıyaslamaktadır (McClanan, 1996, s. 54).

\subsection{Anikia Iuliana ve Ayasofya}

Anikia'nın 524 yılından 527 yılına kadar baniliğini yaptığı kilisenin içinde kendini ve ailesini öven oyma yazıt ve elde edilen gösterişli mimari öğeler, böylesine görkemli bir kilise yaptırmaktaki amacının, soyluluğunu, zenginliğini ve ihtişamını göstermek ve kanıtlamak olduğunu düşündürtmektedir. Nitekim, şiirde Anikia'nın Tanrı Evi'nin Süleyman'ın Tapınağı ile kıyaslanması amacının gücünü göstermek olduğunu kanıtlamaktadır. Ancak Anikia, gücünü kime göstermek veya kanıtlamak istiyordu? Harrison'a (1989, s. 137-139) göre zamanının aşağı tabaka mensubu imparator ve imparatoriçelerine... Theodosios'un soyundan gelen bir prenses olarak aşağı tabakadan imparator lustinos ve lustinianos'un tahtta oturması gücüne gidiyor olmalıydı. Üstelik imparatorun aşağı tabakadan gelmiş karısı imparatoriçe 
Theodora'nın görkemli yapıların banisi olması ${ }^{14}$ ve imparatorluğun en soylu ve zengin kadını olarak görülmesi nedeniyle kendisinin kaybolan gücünü ve etkisini geri getirmek istemesi böylesine görkemli bir kilisenin inşasını seçmiş olmasına önemli bir etken olmuş olmalıdır. Büyük intimalle kocasının, oğlunun ve özellikle kendisinin tahtı daha çok hak ettiklerini düşünüyordu. Çünkü, imparatorluk ailesi soyundan gelen kendisiydi... Siyasi rekabet ve politik güç gösterisi böylesine görkemli bir yapının inşasında kendisi için önemli bir güdü olmuş olmalıdır (Raitt, 2011, s. 1-6).

Kilise, lustinianos'un imparator olduğu yıl olan 527 yılında kapılarını halka açtığında bu lustinianos için önemli bir sorunu da gündeme getirmiştir: Bir kadın nasıl olur da döneminin en gösterişli Tanrı Evi'ni inşa ettirir? Iuliana'nın büyüklüğü ve görkemi ile benzeri görülmemiş bir yapı inşa ettirmesi, kuşkusuz imparatorluğa karşı hoşnutsuzluğunu ifade etmesini sağlayan çok önemli bir araç olmuştu. İmparator dışında birisi özellikle de bir kadın böylesine görkemli bir yapı inşa ettirirse imparatorun da imajının bundan olumsuz etkileneceği açıktır. Hatta, kilise içinde kendisini ve soyunu öven böylesine önemli dizeleri sadece imparatorun kullanımı uygun görülmüşken luliana'nın kullanılması açıkça bir meydan okumadır (Raitt, 2011, s. 6-7). lustinianos bunun altında kalmayacaktı. İmparatorluğun en büyük mimarlarını ve matematikçilerini Anikia'nın yapısından çok daha büyük ve hatta şimdiye kadar yapılan ve yapılacak olan tüm yapılardan daha büyük ve görkemli bir kilise yapmak üzere görevlendirdi (Harrison, 1989, s. 139). Yıllar süren inşa faaliyetlerinden sonra bugün biliyoruz ki, yaptırdığı eser günümüzde bile dünyanın en önemli yapılarından birisi olarak yaşamını sürdürmektedir: Ayasofya...

\subsection{Anikia Iuliana ve tavus kuşu motifi}

Aziz Polyeuktos Kilisesi'nin süslemeleri de mimarisi kadar görkemli ve eşsizdir. Antoloji'deki 55-65 arasındaki dizeler kilisenin süslemeleri hakkında önemli ipuçları vermektedir:

"Orta nefin her iki yanında sağlam kolonların üzerinde duran sütunlar, altından tavanın ışıltısını destekler. Her iki tarafta kemerlerin içine oyulmuş girintiler sonsuz dönen ay ışığını çoğaltmışlardır. Sayısız yollardaki karşılıklı duvarlar, doğanın kayalıkların derinliklerinde yaptığı çiçeksi çimenlikler gibi renklerin muhteşem metalik damarları ile giydirilmiştir. Ve Iuliana'nın hediye ettiği Tanrı'nın evi için onları koruyarak ihtişamlarını saklar." (Paton, 1916, s. 10-11)

$\mathrm{Bu}$ dizelerde kilisenin süslemesinde kullanılan damarlı mermerler, renkli cam ve ametist kakmalardan bahsederek kilisenin süsleme programının ayrıntısı da verilmiştir.

Harrison tarafından yapılan kazılar esnasında İran Sasani sanatında rastlanan son derece stilize desenlere sahip birçok mimariye ait parçalar insitu halinde bulunmuştu. İmpost sütun başlıkları üzerinde stilize meyve ağaçları, hurma palmiyeleri, nar ağaçları ve hurma yaprağı desenleri, üzüm salkımları kilisenin zengin bir süsleme programına sahip olduğunu kanıtlamaktaydı (Şekil 6-7). Çok iyi bir işçilikle yapılmış asma dalları ve yapraklar ve sütun başlıkları geç Roma sanatının Doğu Akdeniz'deki en önemli örnekleri arasındadır (Kuban, 1993, s. 277) (Şekil 7).

${ }^{14}$ Imparatoriçe Theodora'nın banilik faaliyetleri hakkında daha geniş bilgi için bknz: McClanan, 1996, s. 50-72; Unterweger, 2014, s. 97-108. 

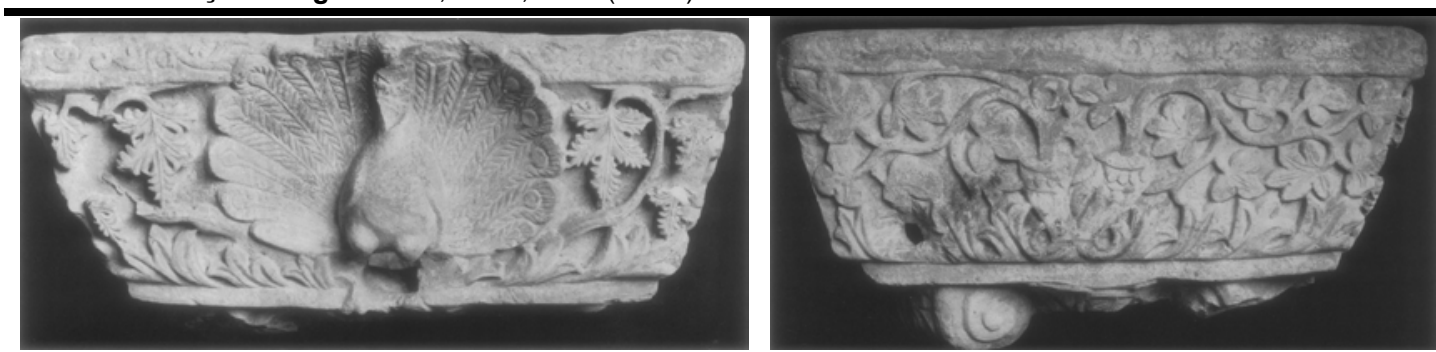

Şekil 6: İmpost sütun başlığı, ön ve arka yüzü (Mango ve Sevcenko, 1961, Fig: 15.)

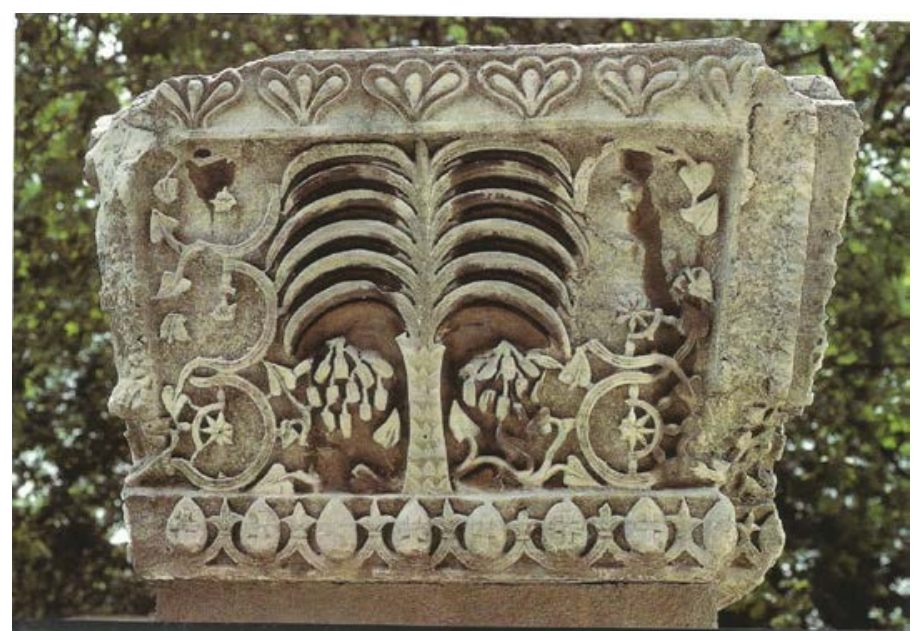

Şekil 7: Sütun başlığı (Harisson ve Fıratlı, 1967, Fig: 13)

Bu kalıntılar arasında en dikkat çekici olanlar, üzerinde oyma yazıtları bulunan saçaklık bloklarıydı. Bunlar dönen asma yapraklarıyla üzümlerden ve ince bir rölyef halinde yaprakların damarlarını bile gösteren ayrıntılı oyulmuş asma yapraklarından meydana gelen desenle kaplıydılar (Harrison, 1989, s. 77-124) (Şekil 8).

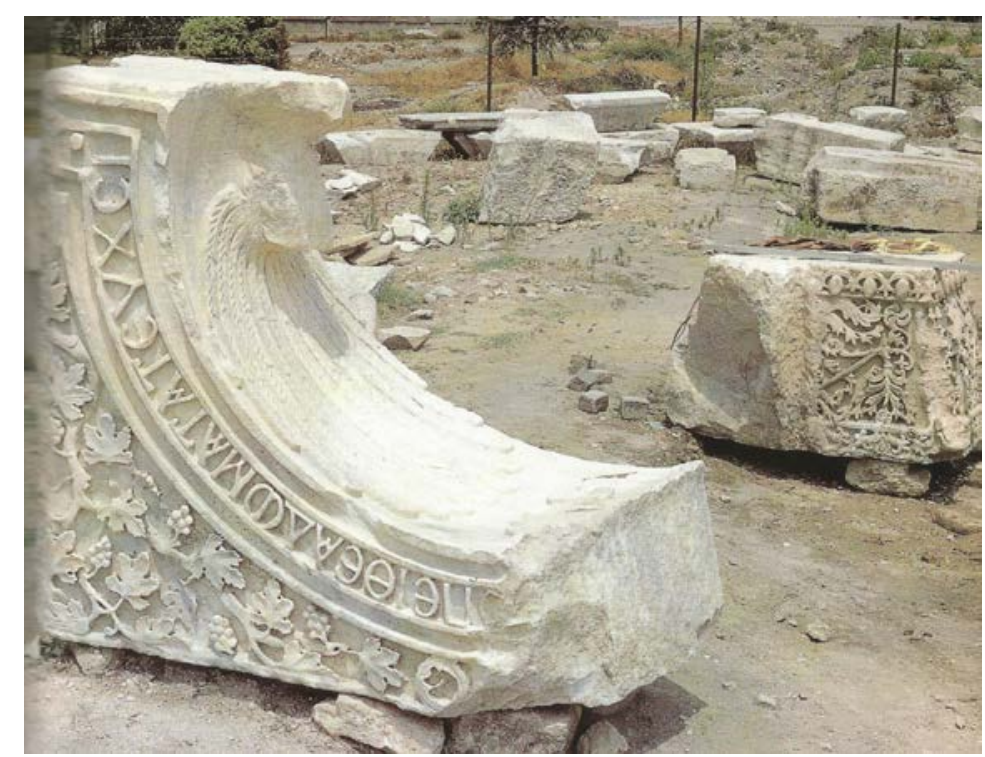

Şekil 8: Şiirin 30. dizesinin bulunduğu tavus kuşu tasvirli kemer ve ayrıntısı (Harrison, 1989, s. 37, Fig: 31) 
Kilisenin içine kazınmış epigram, bir dizi niş içeren saçaklığın çevresindeki bir şerit boyunca devam ediyordu (Şekil 8-9). Nişlerin içinde kalkık veya açılmış kuyruklarıyla yontma tavus kuşlarının kalıntılarına rastlanmıştı. Bu tavus kuşlarının kırık yerlerinden nişleri nasıl doldurdukları anlaşılabiliyordu. Kazılar sonucunda kilisenin içinde otuz tavus kuşu bulunduğu ortaya çıkmıştı. Kuşların ve onları çevreleyen asma desenleri ve yazıtların orijinal görünüşünü tekrar oluşturmaya yetecek sayıda parça izine rastlanmıştı. Asmaların ve harflerin arka planları parlak mavi, kuşlar ve tüyleri yeşil mavi ve altın rengindeydi. Her kuş, oyma rölyef bir kolye takmaktaydı, kakma yeşil cam gözlere sahipti ve gagasında bir nesnenin ve belki de bir lambanın asılı olduğu bir zincir tutuyordu (Connor, 2011, s. 162). Gerçek boyutlarda resmedilmiş bu kuşlar kilisenin içinde kuşkusuz olağanüstü bir görsellik sunmaktaydı ${ }^{15}$.

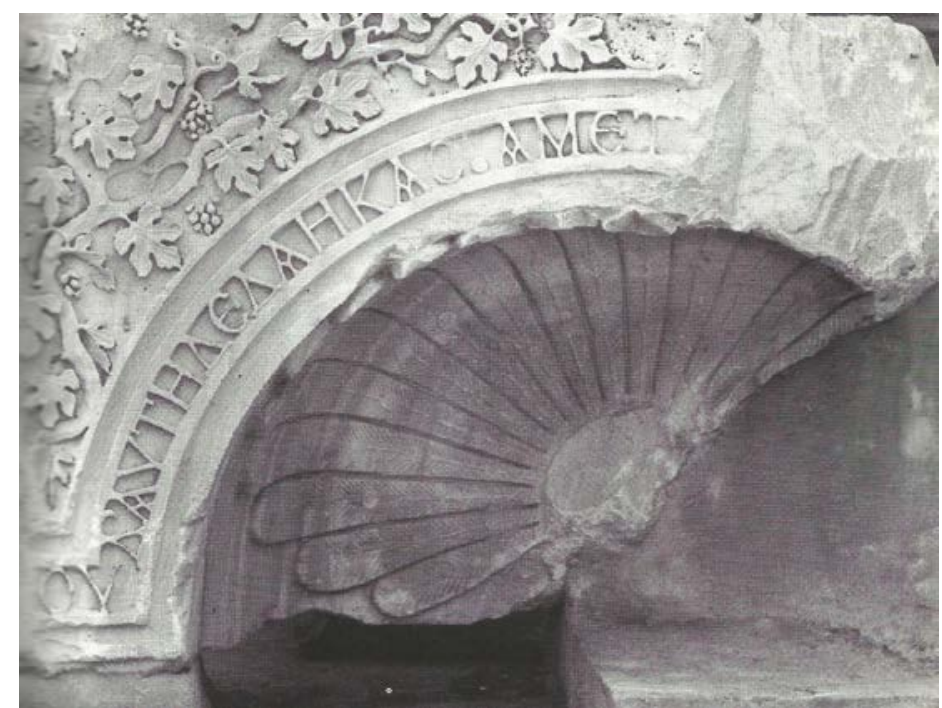

Şekil 9: Şiirin 31. dizesinin bulunduğu niş ve tavus kuşu tasviri (Harrison, 1989, s. 41 Fig: 34)

Antik Çağ'da tavus kuşu Zeus'un karısı Hera'nın simgesi idi. Hera gösteriş meraklısı olmasından dolayı, görkemli ve çalımlı tavus kuşu ona yakıştırılan bir simge olmuştur (Gibson, 2002, s. 165). Hikaye, Zeus'un Argos Kralı İnakhos'un kızı İo'yu görünce kıza aşık olmasıyla başlar. Hera bunu öğrenince büyük bir kıskançlığa kapılır. Zeus da sevgilisini karısının öfkesinden korumak için onu beyaz bir ineğe dönüştürür. Hera, ineğin kendisine verilmesini şart koşar ve İo'nun başına bin gözlü dev Argos'u bekçi olarak diker. Zeus ise Hermes'i Argos'u büyüleyerek öldürmesi için gönderir. Argos ölünce Hera hiddetlenir ve Argos'un 100 gözünü alıp tavus kuşunun tüylerine yerleştirir (Erhat, 1996, s. 152).

Hıristiyan sanatının ilk yıllarında, Tanrı'nın yaradılış güzelliğini sunmak için, görkemli tüylerini tasvir ederek tavus kuşlarının görüntüsünü kullanmışlardı. Tavus kuşları sadece Tanrı'nın güzelliğine değil aynı zamanda kuşun her ilkbaharda tüylerinin dökülmesi doğanın yenilenme gücüne gönderme yaparak dirilişi ve ölümsüzlüğü simgelemiştir. Ruhun kurtuluşu ve sonsuz yaşam simgesi erken Hıristiyanlık döneminde Santa Costanza'nın Mozolesi'nde görüldüğü gibi mozolelerde da çok kullanılan bir simge olmuştur (Baker, 2013, s. 85).

Erken Hıristiyanlık ve erken Bizans döneminde imparatorluk ailesine mensup kadınlar ve aristokrat kadınlar öldükten sonra gömülecekleri yerleri inşa ettirmek istiyorlardı.

${ }^{15}$ Kilisenin dekorasyonu ile ilgili ayrıntılı bilgi için bknz: Harrison, 1989, s. 77-124. 
Eudokia, Aziz Stephanos'a adadığı çok büyük bir kilise inşa ettirdi ve öldükten sonra da burada gömülmeyi istedi ve isteği de gerçekleşti. Theodosios Hanedanlığı'nda imparatoriçe olan diğer kadınlar da mutlaka ya Roma'da ya da Konstantinopolis'te mozolelerinde yalnız ya da kocalarıyla beraber gömüldüler. Anikia'nın da bu kaygılar içinde olmaması imkansızdır. Bu nedenle de en son ve en görkemli yapısını kendi mezar yeri olarak düşünmüş olmalıdır (Connor, 2011, s. 171).

Asma dalları ise, Antik Çağ'da Dionysos ile bağdaştırıır ve Hıristiyan sanatı da ekmek şarap ayinindeki şarabı veya İsa'da yaşamın yenilenmesini simgelemektedir. Tavus kuşları asma yaprakları ile birleşerek yaşamın yenilenmesi ve ölümsüzlüğün simgesi haline gelmiş ve bu simgeler, bu kilisenin gömü yeri olarak planlandığı düşüncesini desteklemişlerdir (Connor, 2011, s. 163). Roma döneminde tavus kuşlarının imparatoriçelerin ruhlarını kutsal tanrılar katına taşıyan kuş olarak betimlendiği ve Romalıların mezar anıtlarına yaptırdıkları tavus kuşu figürlerinin soyluluk göstergesi olduğu (Parman 1993, 387) düşünüldüğünde; kökeni, ailesi ve intişamı ile imparatoriçe olarak kendisini tanımlayan Anikia luliana, kendisinin ve ailesinin gömü yeri olarak planladığı kilisesinin süsleme programını bilinçli olarak kendisini belirlemiş olmalıdır. ${ }^{16}$

Aziz Polyeuktos Kilisesi'nde tüm zarafeti ve intişamı ile izleyenlere görsel bir şölen sunan tavus kuşu figürünün, Anikia'nın banisi olduğu Dioscorides Yazması'nın ilk sayfasında da bulunması (Şekil 10), tavus kuşunun Anikia tarafından bilinçli olarak seçildiğini desteklemektedir. Hatta Connor, tavus kuşunun Anikia'nın bir sembolü veya imzası olduğu fikrini ortaya atmıştır (Connor, 1999, s. 509).

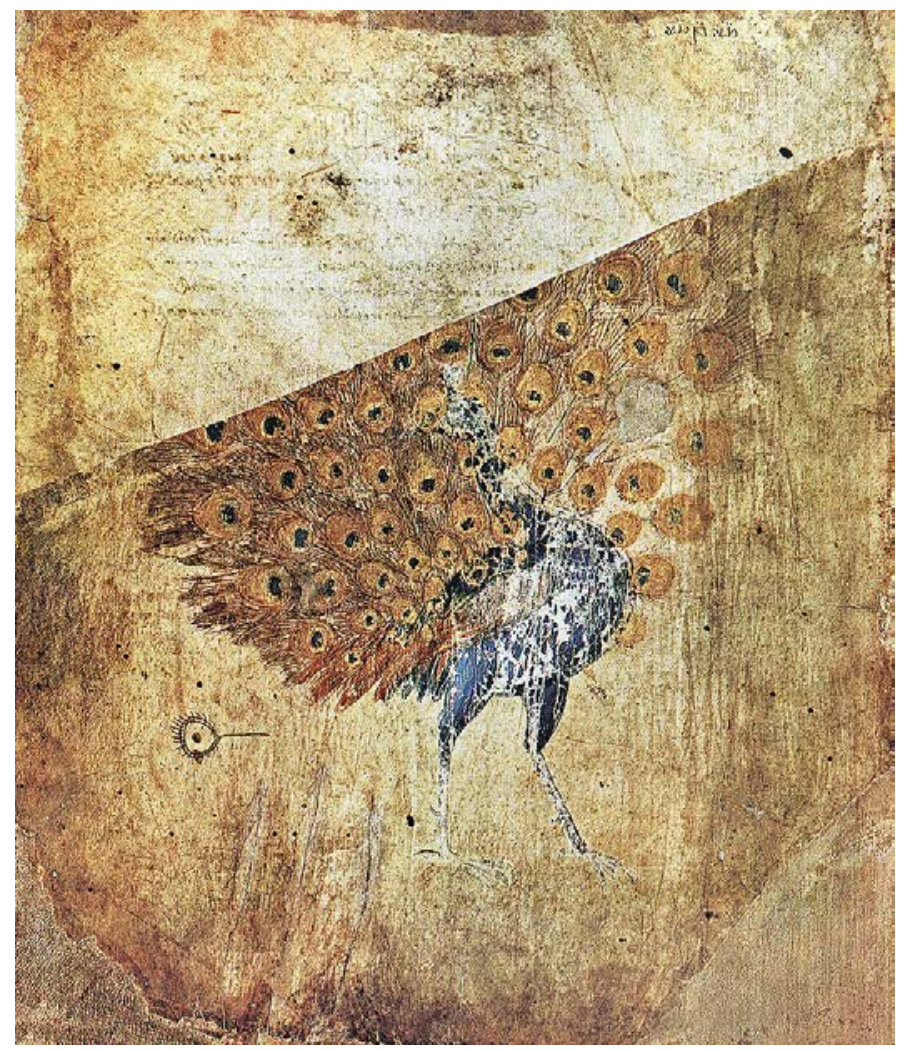

Şekil 10: Dioscorides Yazması, tavuskuşu tasviri, Viyana Dioskorides Yazması, 6. yüzyıl başı, Österreichisches Nationalbibliothek Viyana, Avusturya (Baker, 2013, s. 109, Fig: 1)

${ }^{16}$ Tavus kuşunun simgesel anlamı ile ilgili daha ayrıntıı bilgi için bknz: Maguire, 1987, s. 39, 60. 
Epigramda yer alan son dizeler (65-76), tavus kuşuna ve Hera ile l̇o hikayesine gönderme yaparak Anikia'yı Büyük Konstantinos ile kıyaslarken yaptıklarının öneminden ve büyüklüğünden bahsetmektedir:

"Yüzlerce gözle donatılmış, duvardaki çeşitli tasvirleri doğru okuyan, gözlerini parlayan evin kubbesine dikmiş, hangi usta işlerin ozanı hikaye üstüne hikaye koymak için şimdi alelacele batı cephesine yönelir? Inançsız paganların öfkesini bastırıp putlardan kaçarak bedenini suyla arıtarak Kutsal Üçlemenin ışığını tesis eden Bilge Konstantinos'un verandanın merkezinin üstünde kutsal kalem işlerinin olağanüstü yaratısını görebilirsin. İşte, Iuliana sayısız işırden sonra anne babasının ruhları, kendi hayatı ve şimdi ve kendinden sonraki nesilleri için başardıkları bunlardır."

\section{SONUÇ}

Antik Çağ kültüründen geleneklerin halen baskın olduğu bir dönem olan erken Hıristiyanlık ve erken Bizans dönemlerinde kadınlar, dışa dönük bir toplum yaşamı sürdürmüş ve göreceli olarak özgürlüğe sahip olmuşlardır. Bu kadınlar, entelektüel faaliyetlerde de bulunmuşlar ve kültür hamileri olarak birçok sanatsal eserin oluşumuna katkı sağlamışlardır. Bu katkıların nedeni, kişisel dindarlık ve bağlılık, ailesel istekler ve soy ile ilgili gösterişler gibi kişisel nedenler olabileceği gibi kadınların politik ve sosyal ortamda var olma savaşlarının sonucu da olmuştur. Tanrı'ya şükranlarını sunmak üzere armağan ettiği Aziz Polyeuktos Kilisesi, kalıntıların anlaşıldığı üzere, değerli taşlar ile süslemeleri ve ince oyma işçiliği ile hiçbir masraftan kaçınmayan Anikia'nın cömertliğini ve kendini var etme sürecini gözler önüne sermektedir. Bir kadın olarak böylesine intişamlı bir kilise yaptırmak sadece imparatoriçelere özgü iken Anikia'nın bunu başarmış olması güçlü ve etkin bir kadının sesini duyurur.

Bununla birlikte bu yapılar, bu tür kişisel nedenlerden çok daha önemli kamusal yankıları barındıran yerler olmuşlardır. İmparatorluk ailesine mensup kadınlar, yaşamlarını Tanrı'nın bir lütfu olarak değerlendirmelerinin sonucunda, kiliseleri Tanrı'ya bir teşekkür olarak hediye sunarlardı. Bununla birlikte, Aziz Polyeuktos Kilisesi, tavus kuşları ve asma yaprakları öldükten sonra da hatırlanmak amacı ile ölümsüz olma gayesinde olan ve yazıttaki dualar ile kendinin ve ailesinin ruhlarının kurtuluşunu dileyen bir kadının sesini de duyurmaktadır.

Aziz Polyeuktos Kilisesi öncü planı ve daha öncesine ait görülmeyen ihtişamda süslemeleri ile çok görkemli bir yapı idi. Böylesine özenli bir yapının banisi olmak hiç kuşkusuz Anikia'nın tercihidir. Kilisenin süslemelerindeki ihtişam ve zenginlik, dönemin imparatoru ve onun eşinin soylu olmamasına ve imparatorluğu hak etmediklerine dair bir çığlık da olabilir. 528 yılında hayata veda eden Anikia, lustinianus'un Ayasofya'yı ilk gördüğünde "Süleyman seni geçtim" diye bağırmasını ve belki de içinden "Anikia seni geçtim" diye haykırmasını göremedi. Anikia, Aziz Polyeuktos gibi bir kiliseyi inşa ettirerek lustinianus'a meydan okuyordu ancak önemli bir amacı daha vardı: Zamana meydan okumak. Sadece imparatoriçe olan bir kadının yapabileceği büyüklükte görkemli bir kilise inşa ederek ölümsüzleşmek... 


\section{KAYNAKLAR}

Angelova, Dilianan N, Sacred Founders Women, Men and Gods in the Discourse of Imperial Founding Rome Through Early Byzantium, California University, USA 2015.

Baker, Katherine M, "The Anicia Juliana Codex: A Product of Cultural Inheritance and Appropriation ın 6th Century Byzantium", Oklahoma Üniversitesi yayımlanmamış master tezi, 2013.

Brubaker, Lelie, "Memories of Helena: Paterns in Imperial Female Matronage in the Fourth and Fifth Centuries", Women, Men and Eunuchs, (Ed: Liz James), New York 1997, s. 76-99.

Brubaker, Leslie, "The Vienna Dioskorides and Anicia Juliana", Byzantine Garden Culture, (Ed: Antony Littlewood, Henry Maguire, Joachim Wolschke-Bulmahn), Dumbarton Oaks Research Library and Collection Washington D.C, USA 2002, s. 189214.

Canko, Dilek Maktal, "Bizans Dünyasında ve Sanatında Kadının Yeri”. Ege Üniversitesi Sosyal Bilimler Enstitüsü Yayımlanmamış Doktora Tezi, İzmir 2016.

Ciotta, Gianliugi, "Anikia Iuliana Sarayı Yapılarından Aziz Polyeuktos Kilisesi”. Arkeoloji ve Sanat 141, İstanbul 2012, s. 101-110.

Connor, Carolyn L, "Epigram in the Church of Hagios Polyeuktos in Constantinople and Its Byzantine Response", Byzantion 69, 1999, s. 479-527.

Connor, Carolyn, Bizans'ın Kadınları, Yapı Kredi Yayınları, İstanbul 2011.

Cormack, Robin, Byzantine Art, Oxford History of Art Series, Oxford Univercity Press, 2000 .

Cutler, Anthony, "Bizans'ta İhtişam ve Lüksün Vazgeçilmezliği", Byzantiondan İstanbul'a Bir Başkentin 8000 Yılı, 5 Haziran-4 Eylül 2010, İstanbul: Sabancı Üniversitesi Sakıp Sabancı Müzesi, İstanbul 2010, s. 136-143.

Erbilgin, Seyda Hilal, Theodosios Hanedanında Kadın Banilerin Etkinlikleri, Hacettepe Üniversitesi Sosyal Bilimler Enstitüsü Sanat Tarihi Anabilim Dalı Yayımlanmamış Yüksek Lisans Tezi, Ankara 2010.

Erhat, Azra, "İo”, Mitoloji Sözlüğü, İstanbul 1996, s. 152-153.

Freely, John ve Çakmak, Ahmet S, İstanbul'un Bizans Anıtları, Yapı Kredi Yayınları, İstanbul 2005

Gibson, Clare, Semboller Nasıl Okunur? Resimli Sembol Okuma Rehberi, Yem Yayınları, Çin 2002.

Grant, Michael, Roma'dan Bizans'a, Homer Kitabevi, İstanbul 2000.

Harrison, Martin ve Fıratlı Nezih, "Excavations at Saraçhane in Istanbul: First Preliminary Report", Dumbarton Oaks Papers 19, 1965, s. 230-236.

Harrison, Martin ve Fıratlı, Nezih, "Excavations at Saraçhane in Istanbul: Second and Third Preliminary Reports", Dumbarton Oaks Papers 20, 1966, 222-238. 
Bizans Prensesi Anikia Iuliana'nın Baniliği ve Aziz Polyeuktos Kilisesi

Harrison, Martin ve Fıratlı, Nezih, "Excavations at Saraçhane in Istanbul: Fourth Preliminary Report", Dumbarton Oaks Papers 21, 1967, s. 273-278.

Harrison, Martin ve Fıratlı, Nezih, "Excavations at Saraçhane in Istanbul: Fifth Preliminary Report, with a Contribution on A Seventh-Century Pottery Group". Dumbarton Oaks Papers 22, 1968, s. 195-216.

Harrison, Martin, A Temple For Byzantium, The Discovery and Excavation of Anikia Iuliana's Palace-Church in İstanbul, İngiltere1989.

James, Liz, "Depicting the Public Body", Empresses and Power in Early Byzantium, Leicester Univercity Press, New York 2001, s. 133-147.

James, Liz, "Making a Name: Reputation and Imperial Founding and Refounding in Constantinople", Female Founders in Byzantium (Ed: Lioba Theis, Margaret Mullett, Michael Grünbart, Galina Fingarova, Matthew Savage), Polonya 2014, s. 63-72.

Janick, Lules ve Stolarczyk, John, "Ancient Greek Illustrated Dioscoridean Herbals: Origins and Impact of the Juliana Anicia Codex and the Codex Neopolitanus", Notulae Botanicae Horti AgrobotaniciCluj-Napoca 40 (1), 2012, .Erişim: www.notulaebotanicae.ro. 25.07.2016. s. 09-17.

Kaegi, Walter Emil, "Anicia Juliana", The Oxford Dictionary of Byzantium 1 (Ed: Alexander P. Kazhdan, Alice-Mary Talbot, Anthony Cutler, Timothy E. Gregory, Nancy Patterson Ševčenko), Oxford Univercity Press, New York 1991, s. 99-100.

Kiilerich, Bente, "The Image of Anicia Juliana in the Vienna Dioscurides: Flattery or Appropriation of Imperial Imagery?", Symbolae Osloenses 76:1, 2010, s. 169-190.

Klein, Konstantin M., "Do good in thy good pleasure unto Zion The Patronage of Aelia Eudokia in Jerusalem", Female Founders in Byzantium (Ed: Lioba Theis, Margaret Mullett, Michael Grünbart, Galina Fingarova, Matthew Savage), Polonya 2014, s. 8595.

Kleinbauer, W. Eugene, "Antioch, Jerusalem and Rome: The Patronage of Emperor Constantius II and Architectural Invention", Gesta 45 No: 2, 2006, s. 125-145.

Kuban, Doğan, "Polieuktos (Ayios) Kilisesi", Dünden Bugüne İstanbul Ansiklopoedisi Cilt: 6, Kültür Bakanlığı ve Türk Tarih Kurumu Yayını, İstanbul 1993, s. 276-277.

Maguire Henry, Earth and Ocean The Terrestrial World in Early Byzantine Art, The College Art Association of America, USA 1987.

Mango, Cyril ve Ševčenko, Ihor, "Remains of the Church of St. Polyeuktos at Constantinople", Dumbarton Oaks Papers 15, 1961, s. 243-247.

Mango, Cyril, Bizans Mimarisi (Çev: Mine Kadiroğlu), İstanbul 2006.

McClanan, Anne, “The Empress Theodora and the Tradition of Women's Patronage in the Early Byzantine Empire", The Cultural Patronage of Medieval Women (Ed: J.H. McCash), Atina 1996, s. 50-72.

Müller-Wiener, Wolfgang, İstanbul'un Tarihsel Topografyası, Yapı Kredi Yayınları, İstanbul 2007. 
Nathan, Geoffrey, 'Pothos tes Philoktistou': Anicia Juliana's Architectural Narratology". Byzantine Narrative, Papers in Honour of Roger Scott (Ed: John Burke, Ursula Betka, Penelope Buckley, Kathleen Hay, Roger Scott, Andrew Stephenson), Melbourne 2006, s. $433-443$.

Necipoğlu, Nevra, "Anikia luliana", Dünden Bugüne İstanbul Ansiklopoedisi Cilt: 1, Kültür Bakanlığı ve Türk Tarih Kurumu Yayını, İstanbul 1993, s. 274.

Parman, Ebru, "Bizans Sanatında Tavus Kuşu İkonografisi", Sanat Tarihinde İkonografik Araştırmalar Güner İnal'a Armağan, Hacettepe Üniversitesi Edebiyat Fakültesi Armağan Dizisi: 4, Ankara 1993, s. 387-412.

Paton, W.R, The Greek Anthology 1, Londra 1916.

Raitt, Louisa R, "Anicia Juliana: The Rightful Ruler And Her Controversial Construction" 2011, Erişim: http://www.pugetsound.edu/files/resources/11228 Raitt.pdf, 13.04.2016. s. 1-19.

Theophanes Confessor, The Chronicle of Theophanes Confessor (Çev: Cyril Mango ve Roger Scott), Clarendon Press, 1997.

Unterweger, Ulrike, "The Image of the Empress Theodora as Patron", Female Founders in Byzantium (Ed: Lioba Theis, Margaret Mullett, Michael Grünbart, Galina Fingarova, Matthew Savage), Polonya 2014, s. 97-108.

Yerasimos, Stefanos, “Aziz Polyeuktos'tan Ayasofya'ya Kubbeli Bazilika'nın Doğuşu”, Sanat Dünyamız 69-70 Bizans Özel Sayısı, İstanbul 1998, s. 167-174. 